\title{
解説
}

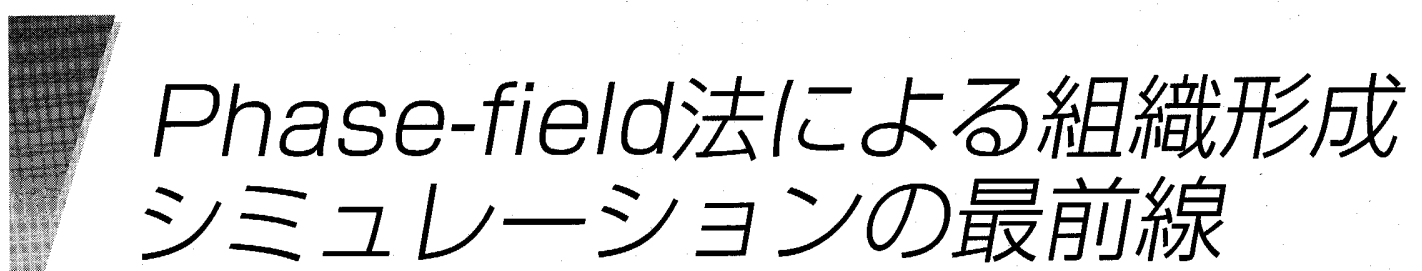

\section{Recent Computer Simulation of Phase Transformations and Microstructure Evolutions Based on the Phase-field Method}

\section{執筆者プロフィール}

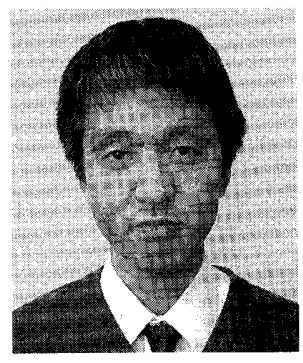

小山＼cjkstart敏幸

Toshiyuki KOYAMA

(01988年名古屋工業大学大学院工学研究科博士前期課程修了, 名古屋 工業大学工学部助手を経て, 2002 年より現職, 博士（工学） (研究・尃門テーマは材料の組織と特性計算に対する計算工学的手法 の開発

(○)正員，(独) 物質・材料研究機構 計算材料科学研究センター 主 幹研究員

(テ305-0047 つくば市千現 1-2-1）

E-mail : KOYAMA.Toshiyuki@nims.go.jp)

\section{1. はじめに}

近年,ナノ・メゾスケールにおける相変態・組織形成 の，連続体モデルに基づくシミュレーション手法として， Phase-field 法 ${ }^{(1)(2)}$ と呼ばれる方法が材料科学. 工学の種々 の分野に広がり始めている．計算対象は現時点で，デンド ライト成長, 拡散相分解 (核形成, スピノーダル分解, オ ストワルド成長など)，規則一不規則変態，各種ドメイン成 長 (誘電体, 磁性体), マルテンサイト変態・形状記憶, 固相結晶成長・再結晶, 転位ダイナミクス, 破壊（クラッ クの進展)，エレクトロマイグレーション，‥等々に及び, ナノ・メゾスケールにおける総合的な組織形成解析シミュ レーション法の一つに成長しつつある. Phase-field 法の枠 組みは，ナノ・メゾスケールに抢ける形成組織の安定性や 形成プロセスを理解する上で非常に有効である。なぜなら ば, Phase-field 法はこのスケールにおける複雑な組織の全 自由エネルギーを基礎に，その組織の形成過程のダイナミ クスをシミュレーションする一般的解析手法であるので， エネルギー論と速度論を兼ね備えた非常に頑健な体系を持 つからである。本稿では Phase-field 法の計算手法の概要お
よび最近の計算例について紹介する。なお計算手法の詳細 については文献（1）（2）を参照していただきたい。

\section{Phase-field 法の概要}

Phase-field 法は連続体モデルに基づく材料組織形成過程 の現象論的なシミュレーション法である. 計算対象が不均 一かつ時間変化する材料組織であるので，この組織形態を 表現するために複数の秩序変数が用いられる。秩序変数を $\mathrm{c}_{i}(\mathrm{r}, t)$ および $\mathrm{s}_{i}(\mathrm{r}, t)$ としよう. $\mathrm{c}_{i}(\mathrm{r}, t)$ と $\mathrm{s}_{i}(\mathrm{r}, t)$ はそれ ぞれ組織内の位置 $\mathrm{r}$ および時間 $t$ における保存および非保 存の変数で, $i$ は秩序変数の番号である. $\mathrm{c}_{i}(\mathrm{r}, t)$ と $\mathrm{s}_{i}(\mathrm{r}, t)$ が “時間および位置における相の場”，すなわち “phasefield”となる。組織形成過程は，これら秩序変数の時間お よび空間変化として記述され，これを計算するための支配 方程式が，以下の非線形発展方程式：

$$
\begin{aligned}
& \frac{\partial C_{i}(\mathrm{r}, t)}{\partial t}=\nabla \cdot\left\{M_{i j}\left[\nabla \frac{\delta G_{s y s}}{\delta C_{j}(\mathbf{r}, t)}+\xi_{c_{j}}\right]\right\}+K_{C} \frac{\partial s_{i}(\mathbf{r}, t)}{\partial t}, \\
& \frac{\partial s_{i}(\mathbf{r}, t)}{\partial t}=-L_{i j}\left[\frac{\delta G_{s y s}}{\delta s_{j}(\mathrm{r}, t)}+\xi_{s_{j}}\right]+K_{s} \frac{\partial C_{i}(\mathbf{r}, t)}{\partial t}
\end{aligned}
$$

である。 $M_{i j}$ と $L_{i j}$ は各々の秩序変数の時間変化に対する易 動度で，正確には秩序変数と温度の関数であるが実際の計 算では定数もしくは温度のみの関数と置かれる場合が多 い. $\xi_{p}$ は秩序変数 $p\left(=c_{j}, s_{j}\right)$ に関する摇動項である（通 常, 乱数による白色ノイズが用いられる). 両式の右辺第 2 項は，それぞれの phase-field 変数の動的なカップリング 項で, $K_{c}$ と $K_{s}$ はカップリング係数である. 実際にこのカッ プリング項が必要な組織形成は, 純金属の凝固におけるデ ンドライト成長やフラクタルパターン成長など, 形態不安 定性が大きな組織形成の場合に限られるようである。

式(1)と（2)に扔いて，G $G_{\text {sys }}$ は不均一な材料組織全体の全 自由エネルギーで, 化学的自由エネルギー $G_{c}$, こう配エネ ルギー $E_{s u r f}$, および弾性ひずみエネルギー $E_{s t r}$ の空間積分： 


$$
G_{s y s}=\int_{r}\left[\begin{array}{l}
G_{C}\left\{C_{i}(\mathrm{r}, t), s_{j}(\mathrm{r}, t)\right\}+E_{s u f f}\left\{C_{i}(\mathrm{r}, t), s_{j}(\mathrm{r}, t)\right\} \\
+E_{s t r}\left\{C_{i}(\mathrm{r}, t), s_{j}(\mathrm{r}, t)\right\}
\end{array}\right] d \mathrm{r}
$$

にて与えられる(電磁気材料の組織形成を扱う分野では, さらに電磁気エネルギーまで考慮される)。個々のエネル ギーがすべて $\mathrm{c}_{i}(\mathrm{r}, t)$ と $\mathrm{s}_{i}(\mathrm{r}, t)$ の関数であるので，式(1) と(2)に扮ける秩序変数 $\left[\mathrm{c}_{i}(\mathrm{r}, t)\right.$ と $\left.\mathrm{s}_{i}(\mathrm{r}, t)\right]$ は，主として 上式のエネルギーを通じて相互作用する。また動的カップ リング項が存在する場合には，これら変数は動的にも相互 作用する。

各秩序变数の時間発展すなわち組織形態の変化過程は, 式(1)と (2)を数值計算することによって求められる. 数学 的には偏微分方程式の数值解析であるので, 数値流体力学 や構造解析などに扔ける定番の手法（差分法や有限要素法 など）が利用できる。

Phase-field 法の発展には大きな二つの流れがあり，一つ は凝固の分野に扔いて展開されている, 複雑な界面形状変 化のダイナミクスを記述するシミュレーションとしての Phase-field 法であり（凝固分野ではフェーズフィールド法 とかた仮名で表記される場合が多い)，いま一つは，主に 固相変態におけるシミュレーションに見られる，相変態に 扔ける秩序变数場それ自身の発展を記述する点に重点を置 く Phase-field 法である，前者では，界面形状の不安定性の ダイナミクスが主として組織形態を支配するので，式（1） と（2）の発展方程式をいかに効率的かつ正確に解くかに重 点が置かれ, 一方, 後者では主にエネルギー的安定性が組 織形態を支配するので，式(3)の全自由エネルギーを正確 に表現することに力点が置かれる．またPhase-field 法は連 続体モデルであるので, 通常, 原子や分子を直接扱うこと はないが, 最近, 結晶格子位置における原子の存在確率を 用いて結晶変態などを解析する試みも行われている. 以下 では，具体的に種々の計算例について見ていこう。

\section{3. 計算例 ${ }^{(1)(2)}$}

図 1 は $\mathrm{Ni}$ 基の耐熱合金の基本系である $\mathrm{Ni}-\mathrm{Al}$ 合金を $973 \mathrm{~K}$ に保持した時の $\gamma^{\prime}$ 析出相組織形成の二次元シミュレー ション結果である. 図中の白い粒子が $\gamma^{\prime}$ 析出相で，黑い 部分は $\gamma$ 母相である. 図の上下および左右方向が $<100>$ 方向で, 図中の $a) \sim f$ )の数值は無次元化した時效時間で ある. 本合金系の組織形態変化には, 析出相と母相の格子 定数の相違に起因する整合ひずみ（格子ミスマッチ）が非 常に重要な役割を果たす。析出粒子間の弾性場の相互作用 は, 隣り合った析出粒子間はもちろんのこと, 析出粒子数 個分ほど離れた距離まで影響を及ばしている。したがっ

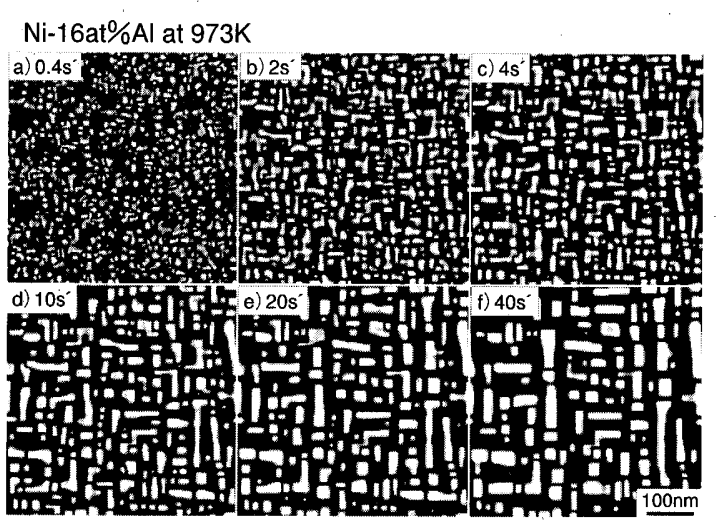

図 $1 \mathrm{Ni}-\mathrm{Al}$ 合金の $\gamma^{-}$析出相組織の成長過程の計算

て, 図1のような組織形成を計算するためには, 弾性場の 長距離相互作用を省略することができない. 本計算では弾 性場はフーリエ変換を利用して逆空間で計算している。 また 析出相の粗大化に伴う粒子の四角形状への変化や $<100>$ 方向への配列は, 弾性異方性に起因している。したがっ て, 内部応力場は少なくとも非等方弾性論に基づき計算す る必要がある。ささに弾性定数が各位置の溶質組成によっ て局所的に異なっている点まで考慮することが望ましい。

図 2 はステンレスの基本系である $\mathrm{Fe}-\mathrm{Cr}$ 合金を 773K に保 持した時のスピノーダル分解過程の三次元シミュレーショ ンである．本合金系は，格子ミスマッチが非常に小さいの で，弾性拘束はほとんど組織形態影響することはなく，方 向性のない組織が形成される。この計算では化学的自由工 ネルギー関数として平衡状態図の熱力学データベースを採 用しているので，実際の $\mathrm{Fe}-\mathrm{Cr}$ 二元系状態図に直接対応し た組織形成の計算となっている.
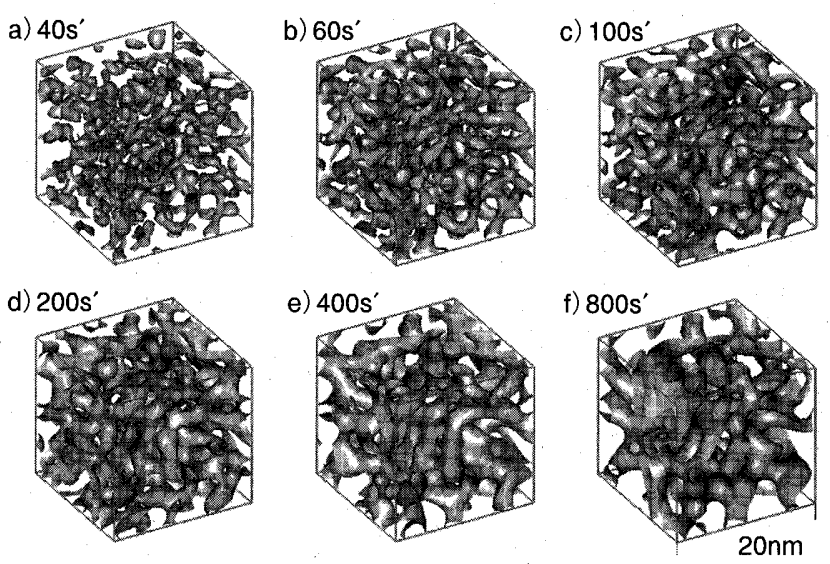

図 2 Fe-40at \% Cr 合金の 773K 等温時効における相分解過 程の計算

図 3 は部分安定化ジルコニアである $\mathrm{ZrO}_{2}-\mathrm{Y}_{2} \mathrm{O}_{3}$ セラミッ クスの相分離過程の二次元シミュレーションである。これ は正方晶におけるスピノーダル分解で, 弾性拘束によって 方向性のある変調構造が形成される. Phase-field 法は連続 


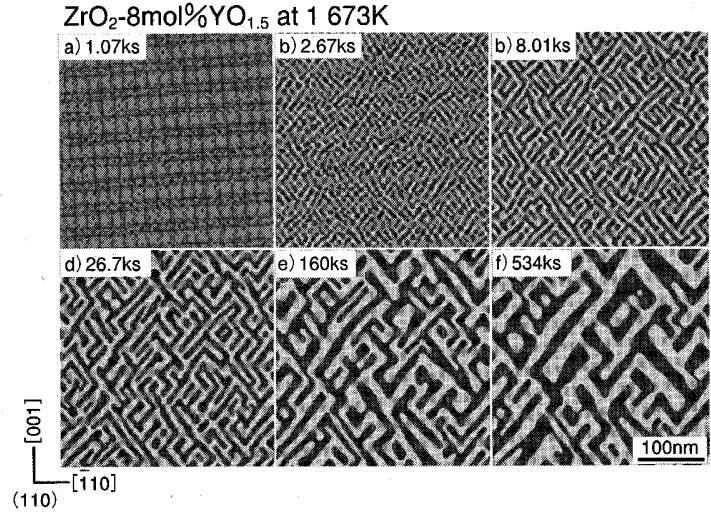

図 3 部分安定化ジルコニアセラミックスの $1673 \mathrm{~K}$ 等温時効における相分解

体モデルであるので，計算対象がセラミックスや高分子 (ポリマーアロイ) であっても，同様の計算理論に基づき 解析することができる.

図 4 は，Fe-40at\%Cr-40at\%Co 合金を外部磁場下（横方 向）において，913Kにて保持した時の二次元相分解シ ミュレーション結果である〔(100) 面〕. 図中の数值は無 次元化した時効時間で, 黒色度が $\mathrm{Cr}$ 濃度を表している. したがって, 図の白い部分が Fe および Co 濃度の高い領域 に対応している。まず相分解初期において，Fe および Co 濃度の高いゾーンが形成され，相分解の進行に伴いゾーン 同時が連なり始め，外部磁場方向に長く伸びたラメラ状の 組織へと発展していくことがわかる．このような組織形成は 実際の本合金系における磁場中組織制御に使用されている.

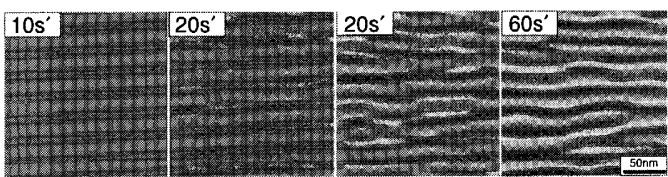

図 $4 \mathrm{Fe}-40 \mathrm{at} \% \mathrm{Cr}-40 \mathrm{at} \% \mathrm{Co}$ 合金の外部磁場 下（横方向）における $913 \mathrm{~K}$ 等温時効の 計算

図 5 は次世代のハードディスク候補として現在活発に研 究されている FePt ナノグラニュラー組織の $923 \mathrm{~K}$ 保持にお ける組織形成過程の二次元計算例である。黒と白の粒状部 分がFePt粒子で，白色度は規則度を表している。した がって，黒い部分は不規則相の FePt（fcc）相で，白い所 は規則相の FePt（L10）相である。地の灰色の部分は非晶 質アルミナ相である。これより，初期 a）b）で粒子は若干 粗大化するものの FePt 相は不規則相であり，c）～e）へと 粒子成長に伴い規則化が進行することがわかる。また e） 左位置の粒子のように，小サイズの粒子の規則化が遅れて いる，e）とf）の左下位置の粒子には逆異相境界も認めら れる，f）と g）の中央位置の消滅しつつある粒子に着目す
ると，粒子サイズが減少するにつれて規則度も低下してい く様子が計算されている.

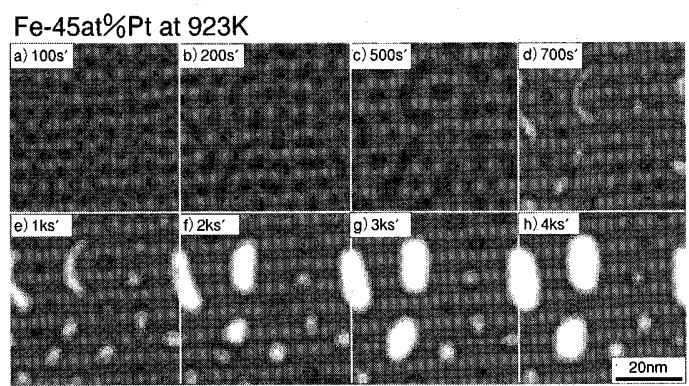

図 5 FePt ナノグラニュラー組織形成と FePt 相の 規則一不規則変態の計算

図 6 は $\mathrm{Ni}_{2} \mathrm{MnGa}$ における双晶ドメイン成長過程（応力お よび磁場誘起の形状記憶現象）の二次元計算結果で，白拉 よび黒色部が，それぞれ $\mathrm{c}$ 軸が横および縦方向の双晶ドメ インである。a）は外場が存在しない状態にて結晶変態さ せた時の双晶組織であり，b)〜d）は上下方向に $1 \mathrm{MPa} の$ 圧縮応力をかけた時の組織変化で, $\mathrm{c}$ 軸が圧縮方向に一致 する黒ドメインが成長していく．続いて e ）～h） は，圧縮 応力はそのままで，横方向に外部磁場をかけた時のドメイ ン成長過程であり，今後は $\mathrm{c}$ 軸が外部磁場方向と一致する 白ドメインが成長する．以上から外部応力と磁気的な力に よって双晶ドメイン境界は可逆的に移動し得ることがわか る.

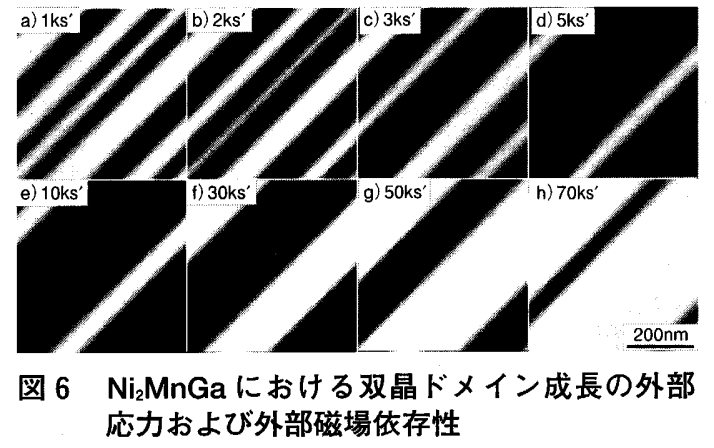

図 7〜9は特に合金系などを指定していない定性的な計 算である。 まず図 7 の) c c）は，純金属に扔ける二次元 デンドライト成長の計算で，白い部分が固相，周りの黒い 部分が液相で，デンドライトの複雑な組織形態形成がリア ルに計算されている。図 8 は結晶成長・再結晶の二次元シ ミュレーション結果で，白い部分が再結晶粒である，上段 および下段はそれぞれ結晶内の初期ひずみが大きいまた小 さい場合に対応する．前者では，いたるところで再結晶粒 が生成・成長し, 後者では組織内の一箇所から再結晶粒が 優先的に成長していく. 図 9 は双極子一双極子相互作用下 にあるドメインの形成・成長過程をモデル化したシミュ 


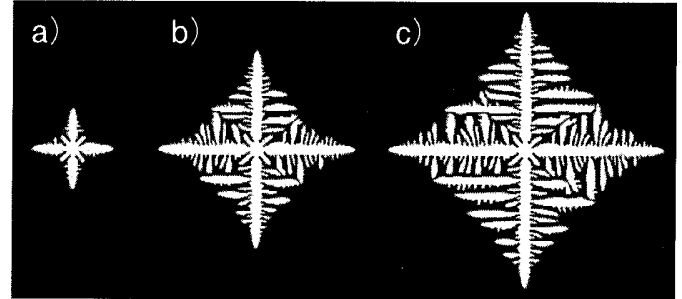

図 7 純金属におけるデンドライト成長過程 の二次元シミュレーション

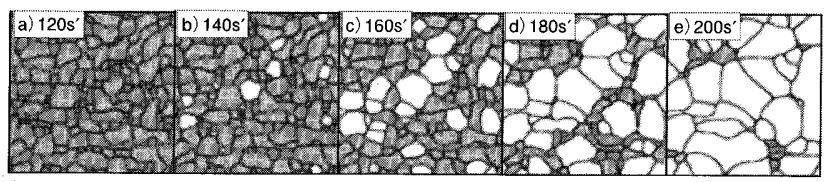

（a）初期ひずみが大きい場合

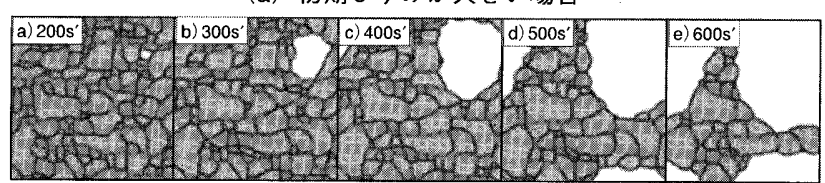

（b）初期ひずみが小さい場合

目 8 結晶粒成長および再結晶の計算

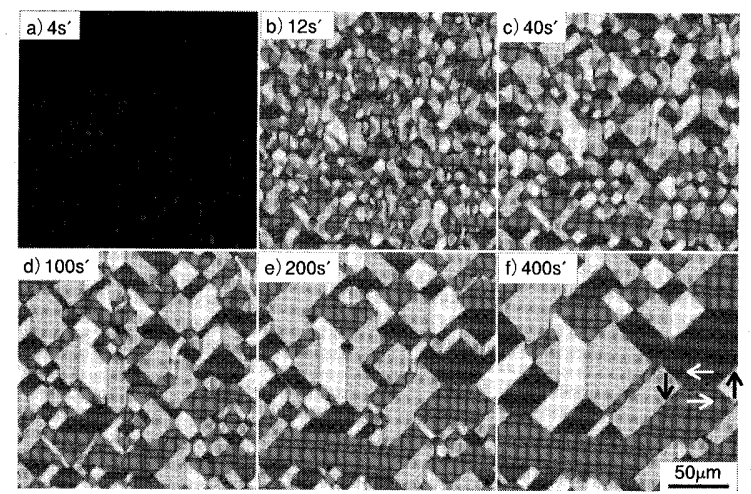

図 9 双極子-双極子相互作用下におけるドメイン 形成・成長の計算

レーションである〔モーメントの方向については，図 f) の矢印を参照]。組織の発展に伴い，いたるところで還流 構造（双極子モーメントが一周して閉じているドメイン配 置）が確認でき，双極子一双極子相互作用エネルギーが小 さくなるように，組織が全体的に自己組織化している様子 が認められる．この計算は強誘電体の分極ドメイン形成の 解析などに利用できる.

以上のように, Phase-field 法はナノ〜メゾに至る種々の 組織形成をモデル化し解析する上で極めて強力な方法論で ある.もちろん，ここで示した組織形態変化（図 7〜9の モデル計算以外）は実際の材料の組織変化をほぼ定量的に 再現している.

\section{4.おわりに}

多変数系の非線形現象を扱う分野において, 現象の予測 は工学的に非常に重要な課題である。しかし, 非経験的に 実用材料における複雑な組織形成の予測を実現にする夢の 手法の出現は，まだまだはるか遠い将来であろう。しか し, 実験データとシミュレーションを併用して, 実際の組 織形成を定量的にモデル化することは現在でも不可能では ない. したがって，多様性に富む複雑な組織形成が関与す る材料設計では, 現象論的な定量モデルを構築することか ら始め, そのモデル自体を系統的にデータベース化し,さ らにそのモデル内において可能な部分から徐々に非経験的 な計算に置き換えていく方法論が工学的な観点から有益と 考えられる。

Phase-field 法は複雑な組織形成過程を, 物理的描像を明 確にしつつ, かなり定量的にモデル化できるため, 例えば これを設計シミュレーションとして利用することにより， 最適な組織形態を探索することができると思われる。つま り実験的にメカニズムを解明し，その組織形成過程を Phase-field 法にてモデリングした後，シミュレーションを 援用して最適な組織を探索することが最も効率的な材料開 発法であろう。近年, 組織の形態デー夕を用いた特性計算 (たとえばマイクロマグネティクスによる磁気ヒステリシ ス解析, 強誘電体の分極ドメイン組織形態に基つく分極ヒ ステリシスの計算, および内部変数理論 ${ }^{(3)}$ や均質化法 ${ }^{(4)}$ を用いた応力ーひずみ曲線の計算など）も進められており， Phase-field 法と組織に基づく特性計算を並列化することに よって, 求める特性を有する組織が一連の組織形成過程の どの条件のもとに存在するかをいち早く探索することが近 い将来可能となると思われる。また本特集にあるようにマ ルチスケール計算が種々の分野で活発に進められている. Phase-field 法が対象とする現象は主に，原子シミュレー ションとマクロな設計シミュレーションの中間のサイズス ケールを有するので, Phase-field 法を, 原子サイズのシ ミュレーションとマクロ設計シミュレーションの仲介役に 活用することも有益と思われる。

（原稿受付 2005 年 5 月 2 日）

○文 献

（1）小山敏幸, 日本鉄鋼協会会報 “小えらむ”, 9(2004)，240-245, 301-305, 376-381, 497-503, 905-910.

（2）小山敏幸, 日本金属学会会報 “まてりあ”, 42(2003)，397-404, 470-474.

（3）井上達雄 - 田中喜久昭 - 長岐 滋, 固体力学と相変態の解析, (1995), 大河出版.

(4) 寺田賢二郎・菊池 昇, 均質化法入門一計算カ学レクチャーシ リーズー, (2003), 丸善. 